\title{
The Effect of Counseling and Training on Public Knowledge about Making Handsanitizer
} from Betel Extract

\author{
Devi Ristian Octavia ${ }^{1}$, Dian Nurafifah ${ }^{2}$, Primanitha Ria Utami ${ }^{1}$, Dimas Prayogo Pangestu ${ }^{1}$ \\ devioctavia1987@gmail.com \\ ${ }^{1}$ Pharmacy education program, Faculty of Health Sciences, Muhammadiyah University of \\ Lamongan, Indonesia \\ ${ }^{2}$ Midwifery education program, Faculty of Health Sciences, Muhammadiyah University of \\ Lamongan, Indonesia
}

Received: January 17, 2021

Received in Revised: February 19, 2021

Accepted: March 5, 2021

\begin{abstract}
Hand sanitizers may help increase hand hygiene compliance as the results of invailability of basic needs for cleaning such as soap or water. Since alcohol has an irritating effect on the skin and burns quickly, it is currently discouraged as an active ingredient. Knowledge of covid 19 is critical for the world to have in order for individuals to be able to make informed choices on how to split the covid 19 transmission chain. This thesis employs a pre-experimental method that employs the One Group Pretest-Posttest Design approach. The paired t test was used to examine the relationship between the two variables, namely the betel leaf extract handsanitizer output preparation and the respondent's knowledge of the handsanitizer making process. Extension has an impact on increasing respondents' awareness of how to make natural hand sanitizers. The paired t-test findings indicate that the Sig. $=0.0000 .05$, indicating that there is a discrepancy between the pretest and posttest. With a mean value of -5.967 , this data indicates the average discrepancy between the pretest and posttest, with a range of -5.383 to -6.551 (95 percent CI), indicating that there is a difference between the pretest and posttest mean values, indicating that the pretest value has an influence on the post test. To stop the spread of Covid19, health care providers and the society must work together.
\end{abstract}

Key words: Hand Sanitizer, Betel Extract, Training

\section{Introduction}

The WHO proclaimed the COVID-19 epidemic a public health emergency of international significance on January 30, 2020. Covid-19 was declared a pandemic by the World Health Organization (WHO) in March 2020, and countries all over the world were warned to track the virus and stop it from spreading. There is currently no FDA-approved drug. Since no study has yet revealed the most possible treatment for this outbreak, society's most powerful and effective defense against an epidemic that threatens not only health but also the environment, politics, and civil order is to deter it from spreading. Hand sanitation, social distancing, and quarantine are the key points in avoiding population dissemination (Güner et al., 2020). As a result, the best ways to managing the transmission of the disease are outbreak avoidance, early virus diagnosis, and recognition of good care protocols (Lotfi et al., 2020). 
The appearance of a new virus, SARS-CoV-2, has posed an alarming threat to global public health. COVID-19 is now being dealt with in a constructive and preventive manner, with the aim of reducing transmission. Hand hygiene is an easy and efficient way to prevent infection spread in public and health-care settings. Unfortunately, little is understood about hand sanitizer's effectiveness against SARS-CoV-2 (Golin et al., 2020).

Coronavirus disease 2019 (COVID-19) begins to evolve worldwide, outstripping health-care systems' capabilities and finances. Therapeutic vaccinations have not changed, but the current solution to preventing case spread is to take prevention action. Since the infection is easily infectious across the respiratory tract (droplets from an infected person, transmitted by coughing or sneezing) and contact with contaminated surfaces, population dissemination and spread can be avoided by practicing good hand hygiene (Beiu et al., 2020)

Hand hygiene has become more essential as a result of the recent COVID-19 pandemic. The Centers for Disease Control and Prevention advises washing your hands daily with soap and water to keep the infection from spreading. Hand hygiene drugs come in a number of formulations, and although each one can be effective against COVID-19, they may also affect the skin's integrity and defensive function (Rundle et al., 2020).

Most alcohol-based hand sanitizers, like the coronavirus, are good at deactivating enveloped viruses. With what is already understood in the literature, it is difficult to recommend one method of hand sanitization over another. Where soap and water are not available, a sufficient amount of cleanser is needed to ensure full hand coverage, and strict adherence is necessary for proper hand hygiene (Golin et al., 2020). Since alcohol has an irritating effect on the skin and burns quickly, it is currently discouraged as an active ingredient. And since alcohol is the main ingredient in khamr, which is haram and punishable as unclean, there is an appreciation of its impurity in its use. As a result, developing non-alcoholic antibacterial active ingredients that are stable and do not cause inflammation is very important (Fathoni et al., 2019). Hand sanitizers with active ingredients of betel leaf extract are more effective in inhibiting the development of S. aureus bacteria than other consumer products that use alcohol as an active ingredient. (2019, Fathoni et al.)

During the 2019 coronavirus disease (COVID-19) pandemic, households are stockpiling and manufacturing hand sanitizer, potentially raising the risk of unintended toxicity in infants. While the World Health Organization has released recommendations for hand sanitizer manufacturing, more people choose to learn from streaming media. YouTube may not be the best place to look for a good hand sanitizer ingredient. Hand sanitizer exposure among children is growing, and health care professionals and parents should be mindful of this and take adequate measures (Hakimi \& Armstrong, 2020).

Knowledge of covid 19 is critical for the group so that individuals can make informed choices about how to behave in order to split the covid 19 transmission chain (Purnamasari \& Raharyani, 2020). The Indonesian people's experience has an effect on COVID-19 prevention efforts. Public efforts to avoid COVID-19 infection can be improved by providing specific, credible, and tailored information (Moudy \& Syakurah, 2020). The aim of this paper is to explain the impact of hand sanitizer therapy and preparation on public awareness of betel leaf extract hand sanitizers (Pipper Bettle).

\section{Methods}


For the One Group Pretest-Posttest Design strategy, this testing design or design uses a preexperimental design. Samples were drawn from people who met the requirements for inclusion. The Integrated Service Post (posyandu) cadres in the village of Baturono, Sukodadi Lamongan district, are the population of interest in this study, with a total of 30 respondents. As a pre-test, the researcher sent the respondents a questionnaire about how to make hand sanitizers. It was also offered advice and instruction on how to make hand sanitizers out of betel leaf extract. As a posttest, respondents were given a questionnaire about how to make hand sanitizers after the intervention. The dependent variable respondents' knowledge of the method for making hand sanitizers was measured using a questionnaire on the procedure for making hand sanitizers. The paired $t$ test was used to examine the relationship between the two variables, namely the betel leaf extract handsanitizer output preparation and the respondent's knowledge of the handsanitizer making process.

\section{Results and Discussion}

Public knowledge about COVID-19 is very important during a pandemic like today. Some knowledge related to COVID-19 that must be understood by the public includes the causes of COVID-19 and its virus characteristics, signs and symptoms, terms related to COVID-19, necessary examinations and the process of transmission and efforts to prevent the disease. (Ganing et al., 2020).

Table 1. Characteristics of Respondents

\begin{tabular}{|l|c|c|}
\hline \multicolumn{1}{|c|}{ Variable } & Frequency & Percentage \\
\hline Age (17-25 & & \\
\hline $\begin{array}{l}\text { Late Adolescence } \\
\text { years) }\end{array}$ & 2 & 6,7 \\
\hline $\begin{array}{l}\text { Early adulthood (26-35 } \\
\text { years) }\end{array}$ & 16 & 53,3 \\
\hline $\begin{array}{l}\text { Late adulthood (36-45 } \\
\text { years) }\end{array}$ & 12 & 40 \\
\hline Early Elderly (46-55 years) & 5 & 16,7 \\
\hline Education & 12 & 40 \\
\hline Elementary School & 10 & 33,3 \\
\hline Junior School & 3 & 10 \\
\hline High School & 16 & 53,3 \\
\hline Higher Education & 8 & 26,7 \\
\hline Employment & 2 & 6,7 \\
\hline House Wife & 4 & 13,3 \\
\hline General employees & & \\
\hline Civil Servant & & \\
\hline Farmer &
\end{tabular}

Table 2. Knowledge Distribution of Respondents based on Respondent Characteristics

\begin{tabular}{|c|c|c|c|c|c|c|c|c|}
\hline \multirow{3}{*}{ Characteristics } & \multicolumn{6}{|c|}{ Knowledge } \\
\cline { 2 - 8 } & \multicolumn{3}{|c|}{ Pre } & Total & \multicolumn{3}{|c|}{ Post } & Total \\
\cline { 2 - 8 } & Low & Mid & High & & Low & Mid & High & \\
\hline
\end{tabular}




\begin{tabular}{|l|c|c|c|c|c|c|c|c|}
\hline Age & & & & & & & & \\
\hline 26-35 years & 0 & 1 & 1 & 2 & 0 & 0 & 2 & 2 \\
\hline $36-45$ years & 6 & 6 & 4 & 16 & 0 & 0 & 16 & 16 \\
\hline 46-55 years & 8 & 3 & 1 & 12 & 0 & 0 & 12 & 12 \\
\hline Total & 14 & 10 & 6 & 30 & 0 & 0 & 30 & 30 \\
\hline Pendidikan & & & & & & & & \\
\hline $\begin{array}{l}\text { Elementary } \\
\text { School }\end{array}$ & 4 & 0 & 1 & 5 & 0 & 0 & & 5 \\
\hline Junior School & 6 & 6 & 0 & 12 & 0 & 0 & 12 & 12 \\
\hline High School & 4 & 3 & 3 & 10 & 0 & 0 & 10 & 10 \\
\hline Graduates & 0 & 1 & 2 & 3 & 0 & 0 & 3 & 3 \\
\hline Total & 14 & 10 & 6 & 30 & 0 & 0 & 30 & 30 \\
\hline Employment & & & & & & & & \\
\hline House Wife & 9 & 5 & 2 & 16 & 0 & 0 & 16 & 16 \\
\hline Farmers & 2 & 2 & 0 & 4 & 0 & 0 & 8 & 8 \\
\hline $\begin{array}{l}\text { General } \\
\text { Employee }\end{array}$ & 3 & 3 & 2 & 8 & 0 & & 2 & 2 \\
\hline Civil Servant & 0 & 0 & 2 & 2 & 0 & 0 & 4 & 4 \\
\hline Total & 14 & 10 & 6 & 30 & 0 & 0 & 30 & 30 \\
\hline
\end{tabular}

Table 3. Distribution of Respondents' Pretest and Postest Knowledge

\begin{tabular}{|l|c|c|c|c|}
\hline \multirow{2}{*}{ Knowledge } & \multicolumn{2}{|c|}{ Pre } & \multicolumn{2}{c|}{ Post } \\
\cline { 2 - 5 } & $\mathrm{N}$ & $\%$ & $\mathrm{~N}$ & 0 \\
\hline Low & 14 & 46,7 & 0 & 0 \\
\hline Moderate & 10 & 33,3 & 0 & 0 \\
\hline High & 6 & 20 & 30 & $100 \%$ \\
\hline
\end{tabular}

The results of the study on the respondent's knowledge based on the characteristics of the respondent (Table 2) show that there is no relationship between knowledge and age, education and occupation of the respondent. The results of this study are in line with those expressed by Wulandari et al., (2020) that age, education, work status and position in the family do not have a relationship with knowledge about Covid-19 prevention. Notoatmodjo (2012) states that knowledge is influenced by several factors, including educational factors, which are an attempt to develop a person's personality and abilities both inside and outside school, both formal and nonformal and lasts a lifetime. It is stated that the higher a person's education, the easier it is for that person to receive information. Current technological developments have provided a variety of mass media that can influence people's knowledge of the latest information, so that communication media such as television, radio, newspapers, magazines and so on have a major influence on the delivery of opinions and knowledge of a person (Zulhafandi; \& Ariyanti, 2020).

In this study the community was given direct exposure to information, namely by extension methods then continued with training or direct practice of making handsanitizers from betel extract. The results of the study (Table 3) regarding the respondents' knowledge before being given the intervention showed that almost half of the respondents had low knowledge about making betel leaf handsanitizers. 
Table 4. Knowledge Distribution of Respondents based on questionnaire points

\begin{tabular}{|l|l|c|c|}
\hline No & \multicolumn{1}{|c|}{ Questioner } & Pretest & Postest \\
\hline 1 & $\begin{array}{l}\text { Handsanitizer is an important item because it can be used } \\
\text { when soap and water are not available }\end{array}$ & 100 & 100 \\
\hline 2 & Potential antibacterial betel extract levels are> 10\% & 56,667 & 76,66667 \\
\hline 3 & $\begin{array}{l}\text { The juice of lime juice in the manufacture of handsanitizer is } \\
\text { effective as an inhibitor of betel extract oxidation }\end{array}$ & 60 & 100 \\
\hline 4 & $\begin{array}{l}\text { Making betel extract handsanitizer by boiling directly with } \\
\text { hot water }\end{array}$ & 13,333 & 93,33333 \\
\hline 5 & $\begin{array}{l}\text { Making betel extract handsanitizer at a temperature of more } \\
\text { than 100 degrees Celsius }\end{array}$ & 53,333 & 100 \\
\hline 6 & $\begin{array}{l}\text { The heating time for making betel extract handsanitizer is 15- } \\
\text { 30 minutes }\end{array}$ & $\begin{array}{l}56,667 \\
\text { Betel leaf extract is easily oxidized, marked by a brown } \\
\text { discoloration }\end{array}$ & 100 \\
\hline 8 & Betel leaf natural handsanitizer can last more than one month & 50,333 & 100 \\
\hline
\end{tabular}

In this study, the community's knowledge was measured using a questionnaire sheet for making handsanitizers. An important point that needs to be understood by the community is the technique of making Handsanitizer from betel leaf extract so that the handsanitizer that has been produced can provide the expected benefits. Handsanitizer is made according to the method Lamote et al., (2020) (Figure 1).

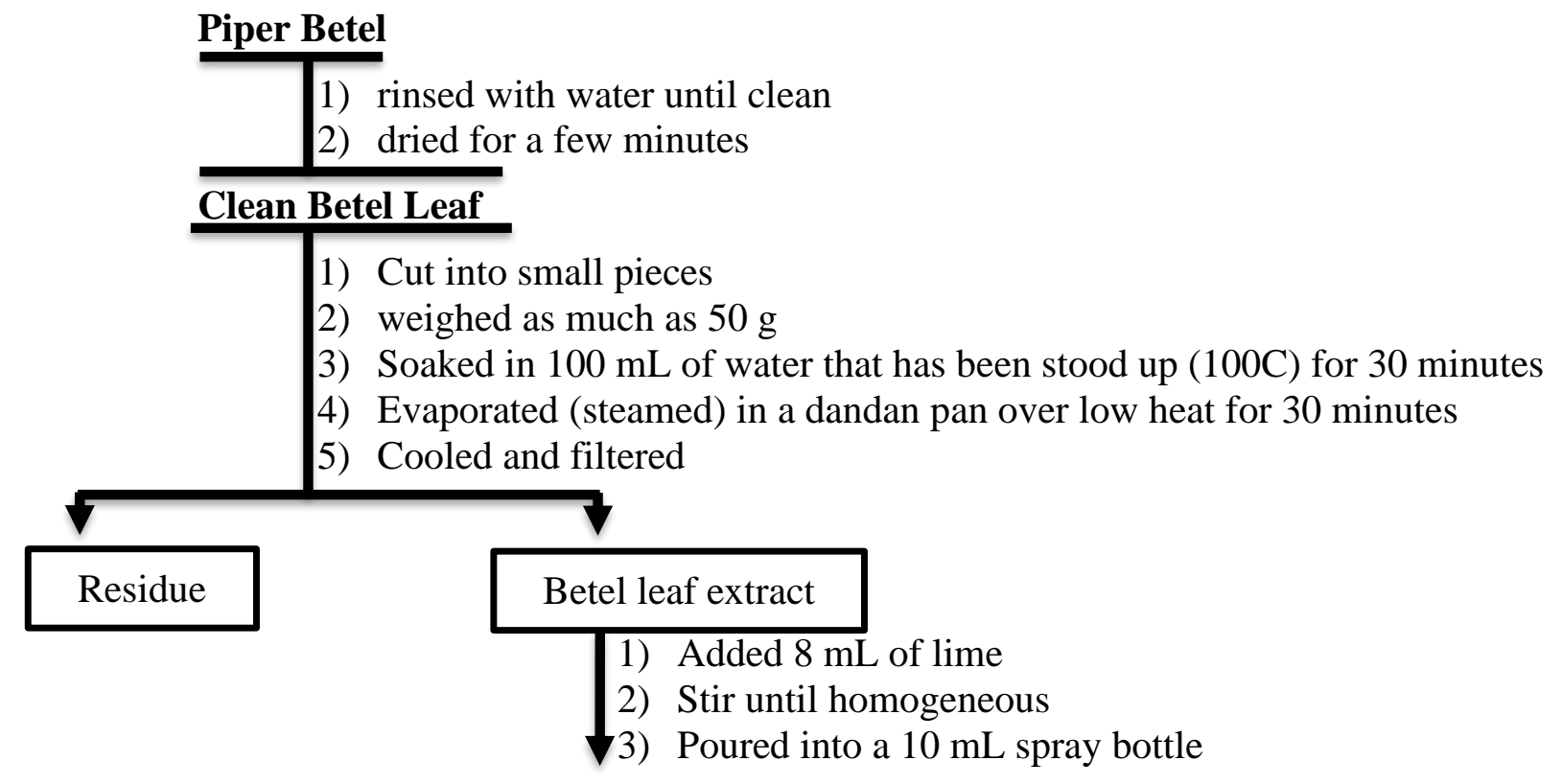

Betel leaf hand sanitize

Figure 1. Handsanitizer manufacturing method (Lamote et al., 2020)

Yanti et al., (2020) revealed that good knowledge in the community can affect attitudes and actions in complying with health protocols so as to prevent the spread of Covid-19. Protocols that regulate interactions such as wearing a mask when leaving the house, not talking at close range, washing 
hands diligently and carrying a hand sanitizer when going out of the house (Pratama \& Hidayat, 2020). Apart from using masks, hand sanitizers are also important because they can be used when soap and water are not available. Handsanitizers can help improve compliance in maintaining hand hygiene when soap and water are not available, as well as being more time efficient in carrying out hand sanitizer applications (Utami \& Octavia, 2020).

Hand sanitizers generally use chemicals that can cause adverse effects on health and the environment. One of the effects of hand sanitizers from chemicals is that they make the skin dry and irritated (Effendi et al., 2020). Currently advances in technology make it easy for people to access information from various sources such as social media Instagram, Youtube or telegram. There are many tutorials circulating in the community about making Handsanitizers according to the formula recommended by WHO, but the drawback in making this hand sanitizer is that the process is very complicated when residents have to make according to WHO standard measurements. In addition, the ingredients for making handsanitizers are difficult to find on the market and also require the right tools and measurements (Rizki et al., 2020).

The use of natural ingredients for Handsanitizer can be an alternative to prevent these side effects. Red betel leaf (Piper crocatum) as a traditional antiseptic which is often used by Indonesians can replace the synthetic medicinal ingredients (Prabowo et al., 2018). Most of the health-related benefits of betel leaf have been attributed to its bioactive phenolic compounds. This highly perishable product extract can be used in organic synthesis, food, beverage, pharmaceutical industries, etc., (Madhumita et al., 2020). The potency of Piper betle extract showed significant inhibitory activity in several types of bacteria (Phumat et al., 2018).

Hand sanitizers made in this study are derived from environmentally friendly materials, such as betel leaf, lime and water as a solvent (Effendi et al., 2020). Water has an important role in the extraction process, where water has good polarity properties so that it is effective at attracting polar bioactive compounds. In addition, the availability of water is quite abundant and easy to find by the community (Lamote et al., 2020).

This hand sanitizer will not cause dry and irritated skin because it is made from natural ingredients. The extraction process of betel leaf bioactive compounds is carried out by means of infusidation. Infundation is extraction by boiling, where the solvent is water at 90C for 15 minutes (Rahmi et al., 2019). Steaming uses low temperatures to prevent damage to bioactive compounds (Lamote et al., 2020)

Lime can be used for making hand sanitizers because it has antimicrobial activity. Lime can inhibit the growth of bacteria in several types of bacteria such as Staphylococcus epidermidis, Salmonella typhi and Enterococcus Faecalis etc. The main components that influence the antibacterial activity of lime are citric acid, malic acid and tartaric acid. In addition, lime also contains flavonoid compounds that can act as antioxidants because they can act as free radical scavengers which are able to release hydrogen atoms from their hydroxyl groups, where the hydroxyl atoms will bind to free radicals so that they become neutral, thereby increasing the stability of the handsanitizer that is made (Prastiwi \& Ferdiansyah, 2018). The handsanitizer produced in the study does not use preservatives, so this natural handsanitizer cannot last for a long time. (Effendi et al., 2020).

Table 5. The results of the pair $t$ test of betel leaf extract handsanitizer production training and the respondents' knowledge of the procedures for making handsanitizers

\begin{tabular}{|c|c|c|c|c|}
\hline Paired Differences & $\mathrm{t}$ & $\mathrm{df}$ & \\
\hline
\end{tabular}




\begin{tabular}{|c|c|c|c|c|c|c|c|c|}
\hline & \multirow[b]{2}{*}{ Mean } & \multirow{2}{*}{$\begin{array}{c}\text { Std. } \\
\text { Deviation }\end{array}$} & \multirow{2}{*}{$\begin{array}{l}\text { Std. } \\
\text { Error } \\
\text { Mean }\end{array}$} & \multicolumn{2}{|c|}{$\begin{array}{l}95 \% \text { Confidence } \\
\text { Interval of the } \\
\text { Difference }\end{array}$} & & & \multirow{2}{*}{$\begin{array}{l}\text { Sig. (2- } \\
\text { tailed) }\end{array}$} \\
\hline & & & & Lower & Upper & & & \\
\hline $\begin{array}{ll}\text { Pair } & \text { PRETEST } 8 \text { - } \\
1 & \text { POST TEST }\end{array}$ & $5,967^{-}$ & 1,564 & ,286 & $-6,551$ & $-5,383$ & 20,891 & 29 & ,000 \\
\hline
\end{tabular}

The findings of the pair $t$ test of betel leaf extract handsanitizer processing preparation and the respondent's knowledge of the handsanitizer producing technique (Table 5) indicate that the Sig. $=0.0000 .05$ indicates that $\mathrm{H} 0$ is refused and $\mathrm{Ha}$ is approved, indicating that the pretest and posttest are different. This data, with a mean of -5.967 , indicates the average discrepancy between the pretest and posttest, as well as the range of -5.383 to -6.551 . (95 percent CI). While the $t$ value, which is $-20,891$, is negative. Since the mean pretest is smaller than the mean posttest, the T count will be negative. It can be inferred that $\mathrm{H} 0$ is rejected and $\mathrm{Ha}$ is accepted in this case since the value of $t$ count $>t$ table, where $t$ count is 20.891> 2.048, indicates that there is a discrepancy between the mean pretest and posttest where there is an influence between pretest and posttest values.

In order to increase the prevention and management of infectious diseases, health promotion is critical. Health cognition includes intelligence and attitudes related to health (Yanti et al., 2020). Counseling and workshops will help the public learn more about COVID-19 and how to avoid it, as well as how to use and make hand sanitizers (Laila et al., 2020).

\section{Conclusion}

Extension has an impact on increasing respondents' awareness of how to make natural hand sanitizers. The paired t-test findings indicate that the Sig. $=0.0000 .05$, indicating that there is a discrepancy between the pretest and posttest. With a mean value of -5.967 , this data indicates the average difference between the pretest and posttest, and the difference between the value of the difference is between -5.383 and -6.551 (95 percent $\mathrm{CI}$ ), indicating that there is a disparity between the mean pretest and posttest, indicating that the pretest value has an influence on the post test.

\section{References}

Beiu, C., Mihai, M., Popa, L., Cima, L., \& Popescu, M. N. (2020). Frequent hand washing for COVID-19 prevention can cause hand dermatitis: management tips. Cureus, 12(4).

Efendi, A. P. P., Sholikah, N., \& Ismawati, R. (2020). Pembuatan hand sanitizer alami dengan memanfaatkan tumbuhan daun sirih di rw 04 desa setia mekar. ABDIPRAJA (Jurnal Pengabdian kepada Masyarakat), 1(1), 29-35.

Fathoni, D. S., Fadhillah, I., \& Kaavessina, M. Efektivitas Ekstrak Daun Sirih Sebagai Bahan Aktif Antibakteri Dalam Gel Hand Sanitizer Non-Alkohol. EQUILIBRIUM Journal of Chemical Enginering, 3(1).

Ganing, A., Salim, A., \& Muslimin, I. (2020). Studi Literatur: Pengetahuan sebagai Salah Satu Faktor Utama Pencegahan Penularan COVID-19. Jurnal Kesehatan Manarang, 6(Khusus), 55-60. 
Golin, A. P., Choi, D., \& Ghahary, A. (2020). Hand sanitizers: A review of ingredients, mechanisms of action, modes of delivery, and efficacy against coronaviruses. American journal of infection control, 48(9), 1062-1067.

Güner, R., Hasanoğlu, I., \& Aktaş, F. (2020). COVID-19: Prevention and control measures in community. Turkish Journal of Medical Sciences, 50(SI-1), 571-577.

Hafandi, Z., \& Ariyanti, R. (2020). Hubungan Pengetahuan tentang Covid-19 dengan Kepatuhan Physical Distancing di Tarakan. Jurnal Kebidanan Mutiara Mahakam, 8(2), 102-111.

Hakimi, A. A., \& Armstrong, W. B. (2020). Hand Sanitizer in a Pandemic: Wrong Formulations in the Wrong Hands. The Journal of Emergency Medicine, 59(5), 668-672.

Laila, L., Hanum, T. I., \& Maha, H. L. (2020). Wash hand education and hand sanitizer preparation workshop to the community in order to prevent COVID-19 transmission. Pengabdian Kepada Masyarakat, 5(April), 428-433.

Lamote, H., Arham, Z., \& Ismaun, I. (2020). Sosialisasi Pembuatan Dan Manfaat Hand Sanitizer Daun Sirih Untuk Aplikasi Pencegahan Penularan Covid-19. Jurnal Mandala Pengabdian Masyarakat, 1(2), 46-53.

Lotfi, M., Hamblin, M. R., \& Rezaei, N. (2020). COVID-19: Transmission, prevention, and potential therapeutic opportunities. Clinica Chimica Acta; International Journal of Clinical Chemistry, 508, 254-266.

Madhumita, M., Guha, P., \& Nag, A. (2020). Bio-actives of betel leaf (Piper betle L.): A comprehensive review on extraction, isolation, characterization, and biological activity. Phytotherapy Research: PTR, 34(10), 2609-2627.

Moudy, J., \& Syakurah, R. A. (2020). Pengetahuan terkait usaha pencegahan Coronavirus Disease (COVID-19) di Indonesia. Higeia Journal of Public Health Research and Development, 4(3), 333-346.

Notoatmodjo. (2012). Metodologi penelitian kesehatan. Rineka Cipta.

Phumat, P., Khongkhunthian, S., Wanachantararak, P., \& Okonogi, S. (2018). Effects of Piper betle fractionated extracts on inhibition of Streptococcus mutans and Streptococcus intermedius. Drug Discoveries \& Therapeutics, 12(3), 133-141.

Prabowo, W. C., Widayat, W., \& Defriana, S. (2018). Formulasi Infusan Daun Sirih Merah (Piper Crocatum) Sebagai Gel Antiseptik Tangan. Jurnal Sains Dan Kesehatan, 1(10), 525-530. https://doi.org/10.25026/jsk.v1i10.59

Prastiwi, S. S., \& Ferdiansyah, F. (2018). Review Artikel: Kandungan Dan Aktivitas Farmakologi Jeruk Nipis (Citrus aurantifolia s.). Farmaka, 16(2), 213-221.

Pratama, N. A., \& Hidayat, D. (2020). Pengetahuan dan Perilaku Masyarakat Memaknai Social Distancing. Jurnal Digital Media \& Relationship, 2(1), 1-10.

Purnamasari, I., \& Raharyani, A. E. (2020). Tingkat Pengetahuan dan Perikalu Masyarakat Kabupaten Wonosobo Tentang Covid-19. Jurnal Ilmiah Kesehatan, 3(1), 125.

Rahmi, H., Rachmania, R. A., \& Wardani, E. (2019). Pembuatan Obat Kumur Alami Daun Sirih Bagi Anggota Aisyiyah di PRA Cabang Perumnas I dan Jakasampurna. Jurnal SOLMA, 
$8(1), 119$.

Rizki, S., Farida, N., Sudarman, S. W., \& ES, Y. R. (2020). Pelatihan Pembuatan Hand Sanitizer pada Masa Pandemi Covid-19 di Kelurahan Purwosari Kota Metro. Jurnal Pengabdian Kepada Masyarakat (JPKM) TABIKPUN, 1(1), 11-18.

Rundle, C. W., Presley, C. L., Militello, M., Barber, C., Powell, D. L., Jacob, S. E., ... \& Dunnick, C. A. (2020). Hand hygiene during COVID-19: recommendations from the American contact dermatitis society. Journal of the American Academy of Dermatology.

Utami, P. R., \& Octavia, D. R. (2020). Pelatihan Pelatihan Pembuatan Handsanitizer dan Pembagian 'Siaga Kit'Sebagai Upaya Pencegahan Covid-19 Di Lamongan. ... (Jurnal Pemberdayaan Masyarakat), 5(2).

Wulandari, A., Rahman, F., Pujianti, N., Sari, A. R., Laily, N., Anggraini, L., Muddin, F. I., Ridwan, A. M., Anhar, V. Y., Azmiyannoor, M., \& Prasetio, D. B. (2020). Hubungan Karakteristik Individu dengan Pengetahuan tentang Pencegahan Coronavirus Disease 2019 pada Masyarakat di Kalimantan Selatan. JURNAL KESEHATAN MASYARAKAT INDONESIA, 15(1), 42-46.

Yanti, B., Wahyudi, E., Wahiduddin, W., Novika, R. G. H., Arina, Y. M. D., Martani, N. S., \& Nawan, N. (2020). Community Knowledge, Attitudes, and Behavior Towards Social Distancing Policy As Prevention Transmission of Covid-19 in Indonesia. Jurnal Administrasi Kesehatan Indonesia, 8(2), 4. 